\title{
Affective Work And Access To Excellence Reorganizing Nordic Welfare
}

\author{
Katrin Hjort \\ Professor in Educational Sciences, \\ Dr.Phil, Institute for the Study of Culture, \\ University of Southern Denmark, \\ Campusvej 55 DK-5230 Odense M, Denmark
}

\begin{abstract}
In the Nordic countries of the $20^{\text {th }}$ century, the caring businesses have usually been handled by women in families or by public institutions of the welfare state. In the $21^{\text {st }}$ century, however, care is becoming a real business. The affective work of education, health and social services is organized by the competitive state or in private welfare enterprises. The economization of welfare leads to the rationalization of work processes and the selection of services and clients. The consequences for the professionals as well as the clients are ambiguous. On one hand, hyper-professionals are developing highly specialized work with the potential to extend human life capacities almost infinitely. On the other hand, sub-professionals are still doing more standardized jobs, and the selection between clients is decreasing. Access to excellent care becomes the central issue, and both professionals and the public are confronted with new ethical challenges.
\end{abstract}

Keywords: welfare state, women's work, affective economy, access to excellence, professional ethics

In 2013, an unexpected and unusual event took place in the Danish labor market. The traditional negotiations between the public employers and the professionals within public service were disrupted. The employers foreshadowed a lockout. The unions threatened strikes. The process did not as usual result in a labor market agreement, but in legislation that made the employers' suggestion into a law (OK 13) with no limits regarding work hours and work load.

The organization of welfare work with education, health and social services in the Nordic countries is undergoing dramatic changes that would have been difficult to imagine just a few years ago. The classical Nordic welfare state model of the $20^{\text {th }}$ century competes with more market-based national and international models. The basic idea of the welfare state model was to improve social equality through public services financed by progressive taxation [5]. This ideal has never been fully realized, and public spending has been a hot political issue since the 1980s. Transforming the Nordic welfare state model into something "sustainable" has been on the political agenda and strongly debated in all countries for several years $[25,26]$. How to do so has been at the core of many severe conflicts of interest, such as OK13. The other conflicts were not as spectacular, however $[31,41]$.

The welfare politics in all the Nordic countries have basically reflected a struggle regarding how to handle fundamental dilemmas between the state and the market, centralization and decentralization, and collectivism and individualization. The ideal has been named "The Competitive State" and the ambition has been a government supporting individuals, enterprises 
and nations to compete on a global market [34]. The dominant practice has been to attempt to implement New Public Management (NPM) tools, such as output control, contracting and competition, between public institutions and between public and private organizations [17, 33]. The consequences of NPM have been an increased amount of work with documentation and quality control. However, as in the United Kingdom, NPM has not necessarily led to better service or reduced spending [9].

It is important to note that neither the construction nor deconstruction processes of the Nordic welfare states have been identical or synchronized in terms of time and tempo. The actual policies in Denmark, Sweden, Norway, Iceland and Finland have depended on factors like:

1. National and international economic conditions (especially oil resources and prices);

2. Power struggles, competition and alliances in the governments (Left/right wing, Social Democrats, Keynesians/Conservatives or Neo-liberalists, [12]);

3. Geo-political localization (relations to the former Eastern or Western Bloc); and

4. Cultural inspiration (Continental and/or Anglo-Saxon).

Membership in the European Union (EU) does not seem to make a visible difference in the reform processes. Norway and Iceland are not members of the EU, but comply very thoroughly with EU standards.

Altogether, the conditions in Nordic public service and professional welfare work have been radically changing within the last 30 years. The core of welfare work has not only been confronted with administrative reforms. The affective work - the processes of "producing and regulating human processes" - is essentially impacted by new economic conditions, new technology and new kinds of localization [11,34]. The consequences for welfare workers and citizens could be significant. On one hand, we are experiencing a new wave of professionalization - increased scientific knowledge, expert competence and ethical commitment. On the other hand, we are being met by de-professionalization - standardization, routinization and "casual" or "careless care" [3, 10, 22].

The crucial question is:

Who is going to have access to perform and receive excellent professional care, and which ethical challenges will emerge consequently?

The aim of this article is to present three analytic models constructed to illustrate the past, the present and the possible future of affective work. I will describe two very different theoretical perspectives that I find useful to combine or confront to understand the transformation of affective work in Nordic welfare: Critical Theory [16, 17, 35] and Post-Structuralist Gender Theory [6]. In paragraph 2, I will draw a model of formal subsumption processes from pre- to post-modernity. Paragraph 3 contains a model of the transformation of the gendered caring work in the Nordic countries in the 20 $0^{\text {th }}$ century, and paragraph 4 outlines hypothetical scenarios for the development of a global affective economy in the $21^{\text {st }}$ century. The concluding paragraph 5 will address the fundamental question about access to excellence and selection in welfare. The perspectivations in paragraph 6, Access to Excellence, and paragraph 7, Freedom's just another word..., discuss the new ethical challenges the professionals - and the societies as a whole - will be confronted with today and tomorrow. The empirical basis will be my research 
on professions conducted in the last 12 years, culminating in a continental doctor. phil. [18-22] 1

\section{PROCESSES OF REAL SUBSUMPTION}

As a part of "the affective turn" within the human and social sciences, the concept of "affects" has become central. The ambition of the affective turn is to break the limits of discourseanalytic approaches that focus exclusively on the use of language. This article takes its point of departure as Michael Hardt's rather unorthodox combination of critical theory and poststructuralist gender research and his definition of "affective work" and "affective economy." From a paradigmatic point of view, critical theory and post-structuralism might be totally incompatible. As theoretical traditions, they love to hate one another, positioning each other as, respectively, determinism and essentialism or voluntarism and relativism. Despite this dynamic - or because of it - Hardt's two tangential theoretical tracks have fruitfully inspired analyses of the past and future of affective work. ${ }^{2}$

Affective work is here defined as work sustaining and extending human life quality and capacity. It will always, deliberately or not, contain a dimension of producing and regulating affective processes - attraction/repulsion, anger/joy, acting out/controlling and so forth. This work is not new historically. It has been and still is a central part of everyday life. The new component is that this kind of work in $19^{\text {th }}$ - and $20^{\text {th }}$-century Europe has been outdifferentiated to relatively autonomous areas, established as a special kind of work and potentially professionalized based on special knowledge, competence and ethics. Marketing, management and media constitute the standard examples of affective work. Education, health and social services are the new forms of welfare work that are potentially institutionalized in different ways today and tomorrow in an affective economy.

An affective economy occurs when affective work becomes the foundation of a market economy. This is not a new phenomenon either, but its extension and expansion are. As Hardt sees it, the affective economy has replaced or supplemented the cognitive economy as the central vehicle of global economic growth in the new millennium [4, 14, 29]. Hardt leans here on the classical materialistic analysis from critical theory, Karl Marx's differentiation between formal and real subsumption [30]. The processes of real subsumption might take place when certain kinds of work - via certain sciences and technologies - may become constructed as separate objects that are available for commodification, commercialization and capitalization. We know these periods as the industrial revolutions: the industrialization of the crafts (work with dead nature via natural sciences, such as physics and chemistry, and stationary energy, such as coal and steam) and the industrialization of farming (work with living nature via natural sciences, such as biology and geology, and mobile technology, such as petrol and gas). The cognitive economy is the exploitation of the cognitive processes within and between human minds via computer science and information technology, and the affective economy is made possible by bio- and psy-sciences and new bio- and self-technologies [38, 39].

\footnotetext{
${ }^{1}$ Doctor Philosophiae (DK: dr.phil/NO: doctor philos/SE: phil.dr) is an old degree of excellency in the Nordic countries inspired by the German continental tradition (established in 1824). The international degree Ph.D. is considered a research education for "young talents with a promising future" (normally comprised of three to four years of training). The Doctor Philosophiae is a degree assigned as the completion of a long and successful research career to "elderly researchers with a promising past" (after demonstrating approximately 12 years of high-quality academic work).

2The different concepts of subject and subjectivity might be the most crucial difference between critical theory and post-structuralist gender-theoretical perspectives. Critical theory prefers the notion of an autonomous subject. Post-structuralism conceptualizes subjectivity/subjectification as a process of positioning/being positioned in different (power) relations.
} 
Model 1: Real subsumption

\begin{tabular}{|c|c|c|c|c|}
\hline & & Object & Science and Technology & Localization \\
\hline $\begin{array}{l}1 . \\
\text { Real } \\
\text { Subs. }\end{array}$ & Industrial Work & Death Nature & $\begin{array}{l}\text { Natural Sciences: Physics and } \\
\text { Chemistry } \\
\text { Stationary Energy: Steam, Coal }\end{array}$ & $\begin{array}{c}\text { Local } \\
\text { National }\end{array}$ \\
\hline $\begin{array}{l}2 . \\
\text { Real } \\
\text { Subs. }\end{array}$ & Farm Work & Living Nature & $\begin{array}{l}\text { Natural Sciences: Biology, } \\
\text { Geology, Gen-technology } \\
\text { Mobile Energy: Gas }\end{array}$ & $\begin{array}{c}\text { National } \\
\text { International }\end{array}$ \\
\hline $\begin{array}{l}3 . \\
\text { Real } \\
\text { Subs. }\end{array}$ & Cognitive Work & Human Cognition & $\begin{array}{l}\text { System Theory and Computer- } \\
\text { science } \\
\text { Information-technology }\end{array}$ & Multinational \\
\hline $\begin{array}{l}4 . \\
\text { Real } \\
\text { Subs. }\end{array}$ & Affective Work & $\begin{array}{l}\text { Human Body and } \\
\text { Soul }\end{array}$ & $\begin{array}{l}\text { Psy-sciences, Self-technologies, } \\
\text { Bio-sciences, Bio-technologies }\end{array}$ & $\begin{array}{c}\text { Local } \\
\text { Transnational }\end{array}$ \\
\hline $\begin{array}{l}5 . \\
\text { Real } \\
\text { Subs. }\end{array}$ & Spiritual Work & $\begin{array}{l}\text { Human Search for } \\
\text { Religious or } \\
\text { Spiritual Meaning }\end{array}$ & $\begin{array}{l}\text { Revitalizing of Ethics, Mystique, } \\
\text { Metaphysics. New Alchemy? }\end{array}$ & "Trans Global" a \\
\hline
\end{tabular}

a We might identify a fifth subsumption where different waves of human search for meaning, such as "New Age," in different versions become still more important objects for financial investments and profit-making.

However, when creating such a periodization, it is important to stress that Hardt himself emphasizes that the construction of different kinds of work does not follow a linear logic but is comprised of simultaneous or non-simultaneous processes established in the global division of labor. Important as well is that the ranking of work according to its significance for economic profit-making and reinvestment does not convey anything about the worth of the work from human or societal perspectives. On the contrary, affective work carried out in civil society, families and public institutions can, for better or worse, be just as necessary for the formal and informal reproduction of society as "real business."

\section{GENDERED CARING WORK IN THE 20TH CENTURY}

Following the line of critical theory, we can draw a picture of three dominant but overlapping phases in the caring work of women in Nordic countries. We do not talk about a universal kind of work or about essential female capacities. We talk about work (still) mostly carried out by women $[22,23,28]$ and of historical constructions and cultural traditions linked to the transformation of the societies from rural to urban. This changing process occurs faster in some areas than others. What in Denmark and Sweden can take four generations can in Norway take three generations and in Finland and Iceland only two [32] In the process, "emotional work" with children, the sick and the elderly is eventually separated from "material production and reproduction" during the century, and women's positions in the societal work division are altered.

Model 2 illustrates the process of the establishment, expansion and erosion of what the German critical theorist Ulrike Prokop [35] has called "the female powers of production." These female powers are constructed as certain dispositions and horizons of expectations within both the privileged and restricted conditions of the nuclear family, which became dominant in the middle of the century. This contradiction produces, as Prokop describes it, on one hand dependency and the tendency to discipline children and husbands and on the other hand a "tremendous number of wishes," longings or fantasies about the realization of love, intimacy, generativity and care. With the emergence of housewives from family isolation, these ideals or "utopian perspectives" were brought into the public institution. "The good life" was to be realized in the institutions dealing with upbringing, human health and safety, but on new 
terms. Love was transformed into a calling of "all the best to all," as the ethos of the welfare state defines it [5] The benefits for the (women) workers were freedom and personal pay, but the costs were wage labor conditions and the permanent, professional ambivalence between empathy and distance.

It is worth noting that the actual discourse on "free choice" and privatization in welfare draws on similar mental patterns. The argument is that the ideals that could not be realized under the bureaucratic restriction of the public institutions will blossom in liberal and flexible private organizations that are sensitive to the needs of the individual. However, prioritization and competition become conditions as well. Caring work is not only about love or a calling, but becomes a career path, and success or failure become possibilities.

Model 2: Work of women in the $20^{\text {th }}$ century

\begin{tabular}{|l|c|c|c|c|l|}
\hline Organization & Ideal & Process & Condition & Defence & \multicolumn{1}{|c|}{ Client } \\
\hline Family & Love & Intimization & Dependency & Disciplining & $\begin{array}{l}\text { The helpless client in } \\
\text { need of care }\end{array}$ \\
\hline $\begin{array}{l}\text { Public } \\
\text { institution }\end{array}$ & Calling & Institutionalizing & Wage labor & Distancing & $\begin{array}{l}\text { The competent client in } \\
\text { need of challenges }\end{array}$ \\
\hline $\begin{array}{l}\text { Private } \\
\text { business }\end{array}$ & Career & Commercializing & Competition & Prioritization & $\begin{array}{l}\text { The calculating client } \\
\text { pursuing his or her own } \\
\text { interests }\end{array}$ \\
\hline
\end{tabular}

Aligned with these processes we see the development of new client constructions, new ways in which the clients can be positioned and position themselves in relation to the professionals and the welfare systems. The beloved "darlings" in need of help and care from the professionals (mothers) to grow are replaced or supplemented by the "competent client" with his or her own resources and the ability to perform. All he or she needs is a challenge. The most recent construction is the "calculating" or even "criminal" client who pursues his or her own interests and acts in strategic and tactical ways to gain the optimal amount of resources. These might include recognition, attention and acceptance, good marks, vital diagnoses or economic advantages. A client might at the same time be positioned in a multitude of divides according to the situation: the helpless customer of the bank, the incompetent parent at the school meeting or the strategic (mis)user of the health system, or vice versa [7] In the competition between the professionals who get to work with "the good clients" and avoid those who seem difficult, being unmotivated or manipulative becomes an issue. Now, all three kinds of organizations designated for caring work are mixed in the competitive state.

\section{THE AFFECTIVE ECONOMY IN THE 21 ${ }^{\text {ST }}$ CENTURY}

When it comes to the context of the affective economy today and tomorrow, Hardt leans on post-structuralist perspectives, especially the work of Patricia Tineto Clough [6]. The first premise here is that the notion of affective processes refers to all human relations and interactions: bodily, cognitive, emotional and symbolic. The second premise is that these processes should not necessarily be processes between individuals but super- or sub-individual processes as well. Here, Clough uses a reference to Gilles Deleuze's term "divide" to signify how minor parts of what traditionally are considered separate individuals with fixed identities and the capacity to act as autonomous subjects are constructed and reconstructed in different relational contexts [8]

The third premise is that the affective economy today is a global phenomenon involving the commoditization, commercialization and capitalization of all living materials, both human and not human. Not only sex but semen, organs, embryos, uteri, breastfeeding, newborns and grown-up individuals are traded globally for medical purposes, emotional reasons and (slave) 
work. The fourth premise is that affective work includes all combinations of organic and nonorganic material. This is not new, either. For example, glasses and canes are well-known aids to extend the capacity of human beings. What is new is the possibility to replace or supplement human organs with advanced technology and transform and transgress the borders of lives with biomedicine and genetic manipulation. In principle, we can live forever. As an extension of this possibility, the fifth premise is that affective work today deals with both the actual and the potential. The question is not only how to learn a lesson, be cured from a disease or saved from a social disaster; the question is how to expand learning and life competences - physical, mental and social - to deal in the most efficient ways with as yet unknown challenges in a rapidly changing and unpredictable future.

The sixth premise is that this affective work can take place not only in reality but also in virtuality. An operation in Copenhagen can, with the help of an operation robot, in principle be performed by a surgeon in Shanghai. All that is needed is a stable Internet connection. Students can be taught by Skype and self-correcting tests, and citizens who need social security can be monitored electronically by GPS. Consequently, the seventh premise is that work becomes still more disconnected in time and space. Space-to-space work can replace face-to-face work. Or, more accurately, the work processes multiply and become more and more differentiated [22, 37]. Face-to-face work can in this context become the most expensive component that is either exclusively specialized or radically standardized.

Model 3: The worldwide affective economy

\begin{tabular}{|l|l|l|}
\hline & Multiplying & Differentiation \\
\hline Object/subject & $\begin{array}{l}\text { All potential life processes } \\
\text { All living materials } \\
\text { All combinations of organic and non- } \\
\text { organic }\end{array}$ & Specialization/prioritization \\
\hline $\begin{array}{l}\text { Financing, } \\
\text { organization, } \\
\text { localization }\end{array}$ & $\begin{array}{l}\text { Private/private-public partnerships } \\
\text { Disconnection in time and space } \\
\text { Global enterprises/local entrepreneurs }\end{array}$ & Centralization/fragmentation \\
\hline Consequences & $\begin{array}{l}\text { Expansion of life capacities } \\
\text { Actual and potential }\end{array}$ & Individualization/selection \\
\hline
\end{tabular}

\section{ACCESS TO EXCELLENCE}

Danish political scientists have, as mentioned, labeled the new state construction around the millennium "the competitive state" or "the competitive social state." The competitive state is seen as a compromise between the classical welfare state and a completely privatized market model for welfare, named "the minimal state" in Denmark. The central question is how to change the national model in which welfare is seen as the redistribution of public spending into the model in which welfare functions as an investment in the competitive power of the nation and the national enterprises in a globalized market. In Denmark, the model is called "Denmark A/S International." Whether the competitive state is a more stable or a transitional phase leading to market-based welfare constitutes a permanent discussion, and attitudes might depend on political views favoring centralistic or liberalistic principles. On the organizational level, the competitive state as described involves new market-like management tools, full or partial out-sourcing and, first and foremost, new partnerships between public institutions and private organizations, and, eventually, civil-society volunteers. This process dissolves the usual distinction between "them and us," the natives and the non-natives, but is replaced or supplemented by a new distinction between the hard-working and the freeloaders, or those who contribute to the community and those who do not [40] 
From a more theoretical point of view, the competitive social state, based on neo-liberal economic thinking, can be analyzed as a display of post-political bio-politics [42]. In a postpolitical era, the borders between left and right are blurred or seem to vanish. Politics grounded in causes or stakeholder interests are replaced with expert administration based on economic science and attempts to attract voters. Politics become scientific and science becomes politicized. Post-political bio-politics addresses the welfare and safety of the population by focusing on the political conduct of people's conduct in their personal lives. Nutrition, exercise, the use and misuse of stimulations and the emotional climate of families, things formerly considered private, become the subject of intense public attention, and a range of recommended self-technologies divide the population into new categories of saints and sinners $[38,39]$. To be a good client and deserve good welfare services, you need to have been responsible and taken good care of yourself. If you haven't, it is your own fault, and the society is not to blame.

The competences and resources required to be a successful client can be illustrated in the following manner:

Model 4: Client competences ${ }^{b}$

\begin{tabular}{|l|l|l|l|l|}
\hline & \multicolumn{1}{|c|}{$\begin{array}{c}\text { AFFECTIVE } \\
\text { RESOURCES }\end{array}$} & \multicolumn{1}{c|}{$\begin{array}{c}\text { COGNITIVE } \\
\text { RESOURCES }\end{array}$} & \multicolumn{1}{c|}{$\begin{array}{c}\text { SOCIAL } \\
\text { RESOURCES }\end{array}$} & \multicolumn{1}{c|}{$\begin{array}{c}\text { FINANCIAL } \\
\text { RESOURCES }\end{array}$} \\
\hline $\begin{array}{l}\text { REQUIREMENTS } \\
\text { OF THE CLIENT }\end{array}$ & $\begin{array}{l}\text { You need to be } \\
\text { able to position } \\
\text { yourself in } \\
\text { positive relation } \\
\text { to the } \\
\text { professionals. } \\
\text { Show your need } \\
\text { for help and } \\
\text { willingness to } \\
\text { help yourself. }\end{array}$ & $\begin{array}{l}\text { You need to be } \\
\text { able to orientate } \\
\text { to and navigate } \\
\text { the procedures of } \\
\text { the organization. } \\
\text { Control and } \\
\text { manage logistics } \\
\text { and coordination. }\end{array}$ & $\begin{array}{l}\text { You need to be able } \\
\text { to establish relevant } \\
\text { networks within and } \\
\text { outside the health } \\
\text { system. Get } \\
\text { information, find } \\
\text { channels for } \\
\text { communication and } \\
\text { influence decisions. }\end{array}$ & $\begin{array}{l}\text { You need to be } \\
\text { potential needs for } \\
\text { help and support. } \\
\text { Obtain knowledge } \\
\text { about collective or } \\
\text { private insurance } \\
\text { and the means to } \\
\text { pay. }\end{array}$ \\
\hline
\end{tabular}

b Recent investigations suggest that, statistically, cultural, social, economic and health capital (understood as both genetic predispositions and lifestyle consequences and mental and physical strength) are decisive factors in obtaining good welfare service. Maybe "aesthetic capital" is a factor as well. Do you look nice and smell good or do you have bad teeth? [27].

To obtain access to excellence - the highly professionalized welfare services - it is convenient to have been healthy if you become ill. A clear brain, decent manners, a strong personal network, family and friends, and favorable economic conditions statistically draw the limit between high-quality services, minimal service and, in the worst-case scenario, no service.

These selection processes concern clients, and they concern professionals as well, not only in their capacities as clients in other systems but in their working lives. Who will be positioned as hyper-professionals with the ability to perform excellence and gain social status and economic possibilities, and who will be reduced to sub-professionals, doing standardized, routinized jobs? 
Model 5: Reorganizing welfare work

\begin{tabular}{|l|l|}
\hline STRENGTHS & WEAKNESSES \\
Hyper-professionals & Sub-professionals \\
Specialization & Standardization \\
\hline OPPORTUNITIES & THREATS \\
Excellence (based on scientific evidence, training & Routine (lack of new knowledge, learning and \\
in handling complicated cases and permanent & training possibilities, lack of time and forced \\
ethical considerations) & insensibility) \\
\hline
\end{tabular}

\section{ETHICAL CHALLENGES}

The construction of the competitive state and the attempts to implement NPM tools place welfare workers in a permanent tension between different and frequently contradictory kinds of logic: administrative logic, professional logic and business logic [1, 13, 22].

\section{Model 6: Ethical dilemmas}

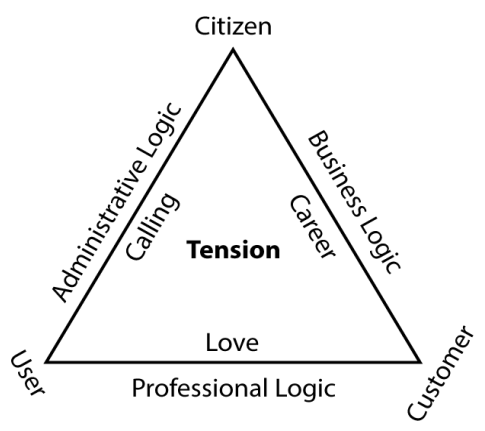

Professionals must handle the constant dilemmas arising between the different considerations: What is most important? To document their activities by filling out the forms sent to the municipality, to concentrate on contact with the clients, for example, the children they must care for or to demonstrate their services to their customers, for example, the parents? Professionals must prioritize between tasks that cannot be done at the same time but must be done within the same time. They need to draw on different kinds of knowledge produced in different ways and with different statuses: scientific evidence, experience and market information. Furthermore, they must balance between different ethical principles: the universalistic welfare ethos (all the best to all), individual considerations and commercial pragmatics.

As an extension of this tension, professionals must (re)consider their own personal investments in welfare work. To some extent, they are supposed to love all, love each and love it. However, personal priorities might be necessary to survive. At this point, we can identify a new holy, or less holy, alliance between the top and the bottom in public organizations. From a bottom-up perspective, rationalization at the personal and organizational levels could seem to be the right solution to erase the overload of welfare dilemmas. "Careless care" - to work casually and not engage too much - can seem like an unavoidable condition. Ethical immunization or brutalization may be a risk [36]. From a top-down perspective, strengthened leadership and strategic management are considered the ultimate tools to secure the future of welfare. However, rationalization, effectivization and marketizing influence the ethical focus of the welfare enterprises. "All the best to all" as the classic welfare ethos may be transformed to "All the best to us": the best students to educate, the best clients to cure and so forth. 


\section{FREEDOM'S JUST ANOTHER WORD...}

The basic cultural and social struggle of the $20^{\text {th }}$ century was about freedom and liberation how to get out of restrictive institutions, families, schools and mental institutions. The basic struggle in the $21^{\text {st }}$ century is about belonging and socializing - how to get in to attractive national or federal states, workplaces, welfare systems, insurance policies and housing. In this struggle, the selection criteria might become differentiated and arbitrary. In Nordic welfare today, formal diplomas and diagnoses become still more important to obtain access to the arenas where excellent care can be performed and received. However, the power to act and to negotiate is central, as is spending power. The criteria are mixed, and one unforeseen event can draw the limit between inclusion and exclusion.

This is a struggle very well suited to create a lot of internal conflicts in various professions. All welfare workers are placed in a paradoxical or contradictory situation. If the transformation of qualities of Nordic public work into new competitive powers in a global affective economy should succeed, the work of professionals gains still more societal importance as the central vehicle of this economy. The professionals obtain new power as subjects and become objects for new power struggles. The outcome of this power play is important not only for the professions but for the future of Nordic societies. To what extent do we want to maintain and sustain the classic Nordic efforts to achieve fairness, social equity and equality in society?

In an affective economy, life and death become political decisions in new ways, as Clough states. In feudal times, the sovereign could decapitate the disobedient. Today, access to life and welfare depends on democratic decision processes. That leaves major ethical challenges. Who decides who is going to live and how? Who possesses the right cards and codes to gain entrance? The bodies in the Mediterranean and the Mexican Gulf are the spectacular examples [24]. The new group of beggars in the streets of Nordic capitals and the new constructions of poor people in Nordic societies are the more familiar examples.

During the past few decades, the personal has become still more political, for better or worse. Today, the political has become personal. Ethical decisions are a part of everyday life, not only in human welfare.

\section{References}

Abbott, A. (1988). System of Professions - Essay on the Division of Expert Labour. Chicago: The University of Chicago Press.

Agamben, G. (2014). For a Theory of Destituent Power. Critical Legal Thinking, 5-2. Avalible at http://criticallegalthinking.com on 16-05-2018.

Aili, C. (2007). Time-formatuve and intermittent work. School and Teachers Work in practise. In C. L. Aili, In Tension between Organization and Profession. Professionals in Nordic Public Service. Lund: Nordic Academic Press.

Boltanski, L. \& Chiapello, E. (1999). The Sociology of Critical Captital. European Journal of Social Theory Vol. 2 No. 3 , p. 359-377.

Briggs, A. (1961). The Wellfare State in Historical Perspektive. European Journal of Sociology, Vol. 2, No. 2, pp. 221258.

Clough, P. T. (ed.) (1999). The Affective Turn - Theorizing the Social (p. 1-12). Durham: Duke University Press. Deleuze, G. (2015). Two Regimes of Madness: Texts and Interviews 1975-1995.” Avalible at http://semiotexte.com on 15-03-2017.

Deleuze, G \& Guattary, F. (2013). A Thousand Plateaus. London/NY: Bloomsbury Publ.

Dixon, R. \& Hood, C. (2015). A Government that Worked Better and Cost less? Evaluating Three Decades of Reform and Change in UK Central Government. Oxford: Oxford University Press. 
Evetts, J. (2011). A New Professionalism? Challlenges and Opportunities. Current Sociology, Vol. 59, No. 4, pp. 406422. DOI: https://doi.org/10.1177/0011392111402585

Fraser, N. (28. January 2017). The End of Progressive Neoliberalism. Avalible at http://www.dissentmagazine.org/online_articles/progressive-neoliberalism-reactionary-populism-nancy-fraser on 20-07-2017

Friedman, R. (1980). Free to Choose: A Personal Statement. San Diego: Hartcourt Publishers.

Friedson, E. (2001). Professionalism: The Third Logic. Chicago: University of Chicago Press.

Gorz, A. (1989): Critique of Economic Reason. London/NY: Verso.

Hardt, M. (1999a). Affective Labor. Boundary 2, Vol 26, No. 2, pp. 89-100. Durham: Duke University Press. Avalibel at http://www.jstor.org/stable/303793 on 16-01-2019

Hardt, M. (1999b). What affects are good for. In P. T. Clough (ed.) The Affective Turn - Theorizing the Social (pp. 1-12). Durham: Duke University Press.

Harvey, D. (2007). A Brief History of Neoliberalism. Oxford: Oxford University Press.

Hjort, K. (1999): En helt anden virkelighed - 12 nye pædagoger om arbejde og uddannelse [Just another reality 12 new pre-school teachers on work and education]. København: Samfundslitteratur

Hjort, K. (2001). Moderniseringen af den offentlige sektor [Modernizing of the Public Sector]. København: Samfundslitteratur.

Hjort, K. (2005). Professionaliseringen i den offentlige sektor [Professionalization in the Public Sector]. København: Samfundslitteartur.

Hjort, K. (2008). Demokratiseringen af den offentlige sektor [Demokratization of the Public Sector]. København: Samfundslitteratur.

Hjort, K. (2012). Det affektive Arbejde [The Affective Work]. København: Samfundslitteratur.

Hochschild, A. R. (2005). Rent a mom' and other services: Markets, meanings and emotions. International Journal of Work Organisation and Emotions, Vol. 1, No. 1, pp.74-86.

Krastev, I. (2017). After Europa. Philadelphia: University of Pennsylvania Press.

Laclau, E. \& Mouffe, C. [1985] (2001). Hegemony and Socialist Strategy. Londom/NY: Verso.

Laclau, E. (1994). Why do empty signifiers matter in Politics. In Weeks, J. (ed), The Lesser Evil and The Greater Good (p. 167-178). London: River Gram Press.

Larsen, K. (2013). Health Capital: New Health Risks and Personal Investments in the Body in the Context of Changing Nordic Welfare States. In Harsløf, I. \& Ulmestig, R. (eds.), Changing Social Risks and Social Policy Adaptions in the Nordic welfare Stats (pp. 165-188). New York: Palgrave Macmillan.

Lorey, I. (2012). State of Insecurity - Government of the Precarious. London/NY: Verso.

Lyotard, J.-F. (1984). The Postmodern Condition. Minneapolis: University of Minnesota.

Marx, K. (1992 [1857]). Grundrisse - Foundation of the Critique of the Political Economy. London: Penguin.

Moos, L. (2013). Transnational Educational Policy and Nordic School Development. London: Springer.

Nielsen, H. B. (2017). Feeling Gender - A Generational and Psychosocial Approach. London: Palgrave Macmillan.

Osborne, E. S. (2009). The New Public Government? London: Routledge.

Pedersen, O. K. (2011). Konkurrencestaten [The Competitive State]. København: Hans Reitzels Forlag.

Prokop, U. (1975). Wieblicher Lebenszusammenhang [Femail Life Context]. Frankfurt am Main: Edition Suhkamp.

Ribers, B. (2018). The plight to dissent: professional integrity and ethical perception in the institutional care work of early childhood educators, European Early Childhood Education Research Journal, 26:6, 893-908. DOI: 10.1080/1350293X.2018.1533707

Rosa, H. (2013). Social Accelleration - A New Theory of Modernity. Columbia: Columbia University Press.

Rose, N. (1999). Powers of Freedom. Cambridge: Cambridge University Press.

Rose, N. (2018). Our Psychiatric Future. London: Polity Press.

Standing, G. (2011). The Precariat - The New Dangerous Class. London/New York: Bloomsbury Academic. 
Wiborg, S. (2013). Teacher Unions in the Nordic Countries: Solidarity and the politics of selvinterests. I T. M. (ed.), The Comparative Politics of Education - Teachers Unions and Education Systems around the world (p. 144-183). Cambridge: Cambridge University Press.

Žižek, S. (2008). Violence. London: Profile Books. 